Article

\title{
Employer Expectations Regarding the Competencies of Employees on the Energy Market in Poland
}

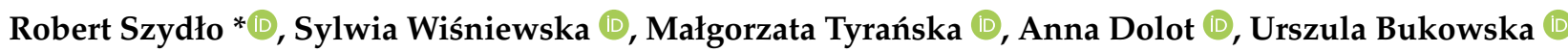 \\ and Marek Koczyński
}

check for

updates

Citation: Szydło, R.; Wiśniewska, S.; Tyrańska, M.; Dolot, A.; Bukowska, U.; Koczyński, M. Employer Expectations Regarding the Competencies of Employees on the Energy Market in Poland. Energies 2021, 14, 7233. https://doi.org/ 10.3390/en14217233

Academic Editor: Ricardo J. Bessa

Received: 28 September 2021

Accepted: 28 October 2021

Published: 2 November 2021

Publisher's Note: MDPI stays neutral with regard to jurisdictional claims in published maps and institutional affiliations.

Copyright: (c) 2021 by the authors. Licensee MDPI, Basel, Switzerland. This article is an open access article distributed under the terms and conditions of the Creative Commons Attribution (CC BY) license (https:// creativecommons.org/licenses/by/ $4.0 /)$.
Department of Labour Resource Management, Cracow University of Economics, 31-510 Cracow, Poland; sylwia.wisniewska@uek.krakow.pl (S.W.); malgorzata.tyranska@uek.krakow.pl (M.T.); anna.dolot@uek.krakow.pl (A.D.); urszula.bukowska@uek.krakow.pl (U.B.); marek.koczynski@uek.krakow.pl (M.K.)

* Correspondence: robert.szydlo@uek.krakow.pl; Tel.: +48-660-715-085

\begin{abstract}
It is because of competencies that there is a possibility of ensuring the strategic safety of each country when it comes to energy security. With the vast development of IT and teamwork, there are various competencies needed in the whole energy sector. The aim of this study is to assess the needs of competencies in the Polish energy labor market as well as the trends among hard ad soft skills also in the context of renewable energy sources. Within an exploratory approach, 245 job advertisements were analyzed using various tools, including general descriptive statistics, Shapiro-Wilk, Kruskal-Wallis H and Mann-Whitney U tests, as well as Spearman's Rho. The research confirmed that teamwork and MS Office are crucial demands of employers. It is also important that the market is diverse when it comes to competence demands, but soft skills are needed in every position, even purely technical ones.
\end{abstract}

Keywords: competence; competency; energy market; labor market; Poland; soft skills; hard skills; labor demand

\section{Introduction}

Energy security is a strategic issue for every country, as the generation and transmission of electricity determine the efficient functioning of the whole economy. National economic development depends on access to energy. It is forecasted that until 2040 the world economy will grow at an average rate of $2.8 \%$ annually. Considering the predicted constantly increasing inefficiency of energy generation, the growth of the global energy sector will be around $1.1 \%$ annually. The importance of conventional energy sources is expected to decline (coal and crude oil-predicted growth of only $0.4 \%$ annually), with a simultaneous rise of renewable energy sources (solar, wind, and geothermal energygrowing by $7.4 \%$ annually). The development of renewable energy should contribute to its share of approximately $20 \%$ in energy production by 2040 [1]. Globally, the energy sector is a sector that is of great interest to investors. According to United Nations Conference on Trade and Development (UNCTAD), gas, water, and electricity projects account for approximately $8 \%$ of global direct investment. Their value in 2011 increased by $43 \%$ compared to the previous year and by approximately $6 \%$ compared to the average level before the global financial crisis (average for 2005-2007) [2]. Global employment in the energy sector reached almost 58 million in 2017, and nearly half of these jobs were linked to the fossil fuel industry [3].

The decarbonization process of the energy system is one of the major concerns of the European Union (EU). The long-term EU strategy is focused on achieving carbon neutrality by 2050 [4-6]. The process is ongoing, but there is still a lot to be done. The EU 2030 Climate and Energy Framework projects energy efficiency as one of the EU's first fuels in each of the 2030 decarbonization scenarios. The aim is that the sum of energy savings and use of 
renewables will overtake the sum of all imported fossil fuels [4,7]. The transition to a green economy and a low-carbon energy system has profound implications for employment worldwide and in Europe. By 2030, about 18 million net jobs could be created worldwide by limiting global warming to $2{ }^{\circ} \mathrm{C}$ by the end of the century [3]. The evolving energy industry is a tremendous challenge for Poland's energy market based on coal-mined in Poland as well as imported from different international sources (including Russia, Australia, Colombia, Mozambique) [8]. Consequently, the situation demands searching for a new business model and the emergence and development of new core competencies, forming sustainable competitive advantages, and optimizing a wide variety of processes in this sector $[9,10]$. It is even indicated that the energy market calls for interdisciplinary competencies [11]. As such, the aim of the article is to analyze the expectations of employers regarding the competencies of employees in the energy market in Poland.

The issue of competencies appeared in the literature at the turn of the 1960s and 1970s with two management psychologists-R. White [12] and DC McClelland [13]. R. White [12] distinguished a specific human factor, which he called competence. On the other hand, DC McClelland [13] stated that although intelligence undoubtedly influences human behavior, the characteristics of a given person (e.g., their motivation, self-perception) that can be observed in life and work situations determine whether a particular behavior will be effective or ineffective in a better manner than intelligence itself. Specific interest in the issue of competencies arose in the 1980s thanks to RE Boyatzis [14], which was due to factors such as increased complexity in the functioning of market entities, the need for professional reorientation, increasing multifunctionality, and the need for employees' multitasking and the perception of "learning" as a critical factor in the success of every organization.

Currently, in the field of management sciences, the concept of competency is considered from the perspective of an employee or job position. It is presented in general or "in detail" and is being divided into hard and soft competencies. The American approach links competency with a specific person, while the British approach links competency with the position. The American concept developed in 1982 by RE Boyatzis [14] focuses on the analysis of people achieving above-average results, particularly on the characteristics of these people (including personal traits, motives, skills, self-image, perception of social role, the scope of knowledge, etc.). In turn, the British concept of competencies, developed in 1987 [15], was created for the needs of the National Vocational Qualifications (NVQs) project, aimed at better adjustment of educational programs to the needs of the labor market, and focused on the workplace and defining tasks and effects from the point of view of requirements set by individual works to their contractors. In this approach, competencies mean the characteristics of work, not employees, and their goal is to define the minimum standards for the performance of a given work and not to identify outstanding performers. In this way, competencies are a summary of tasks and effects and not the personality characteristics of performers. Thus, the first term, "competency", is concerned with behavior and describes "how" standards are achieved. On the other hand, the second term, "competence", means the achieved standard of performance and defines "what" is measured [16].

Generally considered competencies are identified primarily with the employee's abilities that enable the achievement of good work results [14,17-21]. On the other hand, competencies considered "in detail" present the essential attributes of a person, their personality traits, education, professional experience, knowledge, skills, and abilities, as well as practical aspects of their use during the implementation of tasks at the workplace [22,23]. Following B. Mansfield [24], it can be assumed that they constitute the essential feature of a person who functions effectively.

Competencies are an internally complex category. The proof can be found in the literature, classifications of competency components [25-27]. From this perspective, they can be divided into hard and soft competencies. In most studies, hard competencies are defined as a combination of technical and/or cognitive knowledge, and soft competencies as personal behaviors, values, or traits, including ethics, communication, leadership 
skills, interpersonal and teamwork. Hard competencies are task-oriented and have been acquired through education and/or training, and soft competencies are attitudes and emotions expressed through effective communication and interaction with other people [28]. J. Dixon, C. Belnap, C. Albrecht, and K. Lee [29] describe hard competencies as technical or administrative skills that can be quantified and measured.

On the other hand, the term soft competencies cover many different social skills that are separate from technical competencies. Soft skills are also defined as interpersonal, human, personal, or behavioral skills needed to apply skills and technical knowledge into the workplace [30]. These include attitudes and personal characteristics, as well as teamwork, cooperation, empathy, and listening [31]. MM Robles [32] considers the following soft competencies to be the most important: reliability, communication, courtesy, responsibility, interpersonal skills, positive attitude, professionalism, flexibility, honesty, teamwork, and work ethic. Soft competencies are also associated with practical organizational competencies, such as motivation and empathy [33]. Thus, the concept of soft skills is not homogeneous and includes many different components. All the abovementioned researchers' contributions to defining the competence and competency term are presented in Table 1.

Table 1. Researchers' contributions to the competence and competency term.

\begin{tabular}{lcc}
\hline \multicolumn{1}{c}{ Researcher } & Competence Approach ${ }^{1}$ & Competency Approach $^{2}$ \\
\hline White [12] & $\mathrm{X}$ & \\
\hline McClelland [13] & $\mathrm{X}$ & \\
\hline Boyatzis [14] & $\mathrm{X}$ & \\
\hline $\begin{array}{l}\text { National Vocational } \\
\text { Qualifications [15] }\end{array}$ & $\mathrm{X}$ & $\mathrm{X}$ \\
\hline Mansfield [24] & & $\mathrm{X}$ \\
\hline Cheetham [25] & $\mathrm{X}$ \\
\hline Boyatzis [26] & $\mathrm{X}$ \\
\hline $\begin{array}{l}\text { Gholipur [27] } \\
{ }^{1} \text { Is concerned with behavior and describes "how" standards are achieved. }{ }^{2} \text { means the achieved standard of } \\
\text { performance and defines "what" is measured. Source: Own study. }\end{array}$
\end{tabular}

Recognizing the strategic and economic potential of the energy sector and its impact on carbon emissions [34], it is worth paying attention to the competencies that people employed in this sector should have at their disposal in order to fulfill their job requirements. The diagnosis of employer expectations regarding the competencies of employees in the energy market in Poland seems to be particularly important from the point of view of challenges and changes affecting the energy sector in Poland.

This study contributes to a better understanding of the gap between the challenges and changes in the Polish energy sector and competencies needed and expected by crucial employers in that sector. To the best of the authors' knowledge, studies in this area are still limited. The systematic literature review conducted between May and June 2021, with databases such as Scopus, Web of Science, Central Eastern Europe Online Library, Emerald, Elsevier Journal Finder, EBSCO, Wiley Online Library, revealed the small number of articles and the gap. The number of articles with search words "competence" and "energy sector" that is related to this research paper from each database are presented in Table 2. 
Table 2. The number of articles in presented databases.

\begin{tabular}{lc}
\hline \multicolumn{1}{c}{ Database } & Number of Related Articles \\
\hline Scopus & 3 \\
\hline Web of Science & 4 \\
\hline Central Eastern European Library & 0 \\
\hline Emerald & 2 \\
\hline EBSCO & 1 \\
\hline Wiley Online Library & 0 \\
\hline Source: Own study. &
\end{tabular}

All the books and articles concerning competencies in the energy sector since 2015 have been in the scope of interest of the authors. For the vast topic exploration, even older articles were accepted. What is more, the approach connected with analyzing the job offers was started by the authors. No other articles presenting this approach have been found.

\section{The Energy Market in Poland}

The continuity and stability of electricity supplies in Poland are guaranteed by a group of entities creating subsystems within the National Power System (NPS). These entities are separate companies subject to independent institutions and regulations. The subsystems that make up the NPS are the generation subsystem, transmission network, and distribution network. Their functioning is regulated by numerous legal acts created at the level of the European Union and Poland's government. Among the national acts in Poland, the most important is the Energy Law from 10 April 1997 [35], which takes into account the directives of the European Communities. Article 16 of this Act concerns energy companies, which means all entities conducting economic activity in the scope of (a) production, processing, storage, transmission, distribution, or trade of fuels or energy, or (b) transmission of carbon dioxide, or (c) reloading of liquid fuels.

The generation subsystem includes system power plants, industrial power plants, and combined heat and power (CHP) plants, local CHP plants, as well as hydro, wind, solar, biomass, and biogas power plants. The generated energy is distributed through the transmission network: $750 \mathrm{kV}, 400 \mathrm{kV}$, and $220 \mathrm{kV}$ power lines and stations. The transmission network is owned by a single operator, which is called PSE Operator. The end-user receives energy thanks to the distribution and distribution grid, which includes $110 \mathrm{kV}$ lines (owned by PSE Operator due to its specific nature) as well as medium and low voltage lines. End users (companies and households) have the right to choose an electricity producer, but the choice of the distributing company (final supplier) depends on the geographic location [36].

Traditionally, the Polish energy sector is based on fossil fuels, the extensive resources of which are located in Poland - the ninth-largest deposits in the world. Two primary fuels play a crucial role in the structure of electricity production - hard coal and lignite [37]. As shown in Table 2, the importance of these fuels is systematically decreasing. In 2019, their share in electricity production in Poland was less than $78 \%$, while in 2010, it was over $90 \%$. At the same time, the capacity of power plants based on renewable energy sources is increasing, as shown in Table 3. 
Table 3. Gross installed capacity of power plants (in MW).

\begin{tabular}{ccccc}
\hline Year & $\begin{array}{c}\text { Thermal Power } \\
\text { Plants }\end{array}$ & $\begin{array}{c}\text { Hydroelectric } \\
\text { Power Plants }\end{array}$ & $\begin{array}{c}\text { Wind and Solar PV } \\
\text { Power Plants }\end{array}$ & Total \\
\hline 2010 & 32,648 & 2280 & 1286 & 36,214 \\
2011 & 33,347 & 2276 & 1972 & 37,595 \\
2012 & 33,207 & 2281 & 2715 & 38,203 \\
2013 & 32,818 & 2289 & 3564 & 38,671 \\
2014 & 32,985 & 2301 & 4057 & 39,343 \\
2015 & 33,048 & 2306 & 5030 & 40,384 \\
2016 & 32,970 & 2319 & 5977 & 41,266 \\
2017 & 35,002 & 2392 & 6113 & 43,507 \\
2018 & 35,523 & 2385 & 6405 & 44,313 \\
2019 & 37,592 & 2384 & 7461 & 47,437 \\
\hline
\end{tabular}

${ }^{1}$ Public thermal power plants using: hard coal and lignite and non-public thermal power plants. Source: own study based on the Statistical Yearbook [38-41].

Art. 1, point 12 The Energy Law of 10 April 1997 [35] obliges energy companies to draw up a development plan to meet the current and future demand for gaseous fuels or electricity for a period of at least than three years. The transmission system operator prepares this plan for a period of 10 years. However, it should be updated at least every three years, and the distribution system operator for a period of at least five years. The Development Plan for meeting the current and future electricity demand for the years 2021-2030, prepared by PSE, forecasts that the coming decades will bring significant structural changes in the National Electricity System. These changes will include:

1. Increase in total net generating capacity of sources of production to the level of 72.1 GW by the Project Polish Energy Policy until 2040, 62.6 GW by the National Plan for Energy and Climate in 2040, an increase of approximately $60 \%$ and $40 \%$ compared to 2019;

2. A significant decrease in the role of coal-fired system units-their share in the net installed capacity will be reduced to approximately $20 \%$ in 2040;

3. Increase the proportion of renewable energy sources (mainly from wind turbines and solar panels), the aforementioned produced electricity to approximately $32 \%$ in 2030 and $40 \%$ in 2040.

4. A significant increase in the share of gas units.

The data presented in Table 4 shows that since 2015 the revenue of electricity generated by professional thermal power stations has been systematically decreasing, although still over $70 \%$ of electricity production is based on conventional fuels. Nevertheless, the revenue of energy produced by hydro, wind, and solar power plants in 2019 has increased threefold compared to 2010, although their number peaked in 2018. In the analyzed period, a significant, almost threefold increase in electricity imports was also noted. The highest energy consumption was recorded in 2018, which can be attributed to, among other things, economic growth.

Since the beginning of the transformation of the energy sector in Poland in 1997, the entity structure of the electricity market has been systematically changing. The result of the ongoing processes of consolidation of capital groups is a high degree of concentration. According to data from the Energy Regulatory Office, in 2011, the three largest producers (PGE Polska Grupa Energetyczna SA Capital Group, TAURON Polska Energia SA Capital Group, EDF) had more than half of the installed capacity and were responsible for almost two-thirds of electricity production in the country [42]. EDF actives were bought out by other energy capital groups and will not be considered in the following article).

The data of the Energy Regulatory Office from 2021 shows that for several years the largest market share (in 2020, it was 40.6\%) in the electricity generation sub-sector has the PGE Polska Grupa Energetyczna SA capital group [43]. The three largest producers, which also include the capital groups ENEA SA and TAURON Polska Energia SA, in 2020 "had a 
total of almost two-thirds of the installed capacity and were responsible for approximately $62 \%$ of electricity production in the country" [43]. However, in 2020 a decrease in the importance of generators operating in the ENEA SA capital group was recorded.

Table 4. Electricity balance (in GWh).

\begin{tabular}{|c|c|c|c|c|c|c|c|c|c|}
\hline Year & Supply & $\begin{array}{c}\text { from } \\
\text { Domestic } \\
\text { Sources- } \\
\text { Generation }\end{array}$ & $\begin{array}{l}\text { Public } \\
\text { Thermal } \\
\text { Power } \\
\text { Plants }\end{array}$ & $\begin{array}{c}\text { Hydroelectric } \\
\text { Power Plants, } \\
\text { Wind and Solar } \\
\text { PV Power Plants }\end{array}$ & Imports & Use & $\begin{array}{l}\text { Domestic } \\
\text { Con- } \\
\text { sumption }\end{array}$ & Exports & $\begin{array}{c}\text { Losses and } \\
\text { Statistical } \\
\text { Differences }\end{array}$ \\
\hline 2010 & 163,968 & 157,658 & 144,541 & 5152 & 6310 & 163,968 & 144,453 & 7664 & 11,851 \\
\hline 2011 & 170,328 & 163,548 & 149,242 & 6469 & 6780 & 170,328 & 147,668 & 12,022 & 10,638 \\
\hline 2012 & 171,942 & 162,139 & 146,480 & 7841 & 9803 & 171,942 & 148,415 & 12,643 & 10,884 \\
\hline 2013 & 172,381 & 164,580 & 146,665 & 9791 & 7801 & 172,381 & 149,812 & 12,322 & 10,247 \\
\hline 2014 & 172,566 & 159,058 & 139,771 & 11,354 & 13,508 & 172,566 & 150,974 & 11,342 & 10,250 \\
\hline 2015 & 179,403 & 154,076 & 142,804 & 13,350 & 14,459 & 179,403 & 154,076 & 14,793 & 10,534 \\
\hline 2016 & 180,651 & 166,634 & 140,971 & 15,333 & 14,017 & 180,651 & 159,138 & 12,018 & 9495 \\
\hline 2017 & 183,736 & 170,465 & 140,614 & 18,108 & 13,271 & 183,736 & 162,756 & 10,984 & 9996 \\
\hline 2018 & 183,855 & 166,840 & 140,010 & 15,487 & 13,816 & 183,855 & 166,840 & 8121 & 8894 \\
\hline 2019 & 181,858 & 165,662 & 129,006 & 15,764 & 17,868 & 181,858 & 165,662 & 7245 & 8951 \\
\hline
\end{tabular}

${ }^{1}$ Until 2014, the statistics included biogas plants instead of solar plants. In the comparison from 2013, the category was defined as "water (together with other renewable sources)." Source: own study based on the Statistical Yearbook [38-41].

Table 5 presents data on the leading entities of the energy sector in Poland. In addition to the three abovementioned capital groups, the Energa Group was also included. In April 2020, PKN ORLEN became the dominant shareholder of Energa SA, which was considered a factor that potentially increases its importance in the energy market.

Table 5. Characteristics of the leading capital groups generating electricity in Poland (2020).

\begin{tabular}{|c|c|c|c|c|c|c|}
\hline Company & $\begin{array}{l}\text { Total } \\
\text { Installed } \\
\text { Capacity }\end{array}$ & $\begin{array}{l}\text { Installed } \\
\text { Capacity from } \\
\text { Renewable } \\
\text { Sources }\end{array}$ & $\begin{array}{l}\text { Sale of } \\
\text { Energy to } \\
\text { end Users }\end{array}$ & $\begin{array}{l}\text { Electricity } \\
\text { Production }\end{array}$ & $\begin{array}{c}\text { Total Length } \\
\text { of the Power } \\
\text { Line }\end{array}$ & $\begin{array}{l}\text { Renewable Electricity } \\
\text { Production }\end{array}$ \\
\hline PGE CG & 17.96 GWe & 2.326 GWe & $\begin{array}{l}\text { 40.64 TWh } \\
32.43 \mathrm{TWh}\end{array}$ & $58.13 \mathrm{TWh}$ & $295,613 \mathrm{~km}$ & $2.66 \mathrm{TWh}$ \\
\hline TAURON CG & 6.1 GWe & $0.7 \mathrm{GW}$ & $\begin{array}{l}\text { (wholesale: } \\
\text { 13.19 TWh) }\end{array}$ & 12.5 TWh & $241,576 \mathrm{~km}^{2}$ & $2 \mathrm{TWh}$ \\
\hline ENEA CG & $6.3 \mathrm{GW}$ & $0.43 \mathrm{GW}$ & 19.4 TWh & $22.5 \mathrm{TWh}$ & $\begin{array}{l}119,300 \mathrm{~km} \\
(\mathrm{Q} 12021)\end{array}$ & \multirow[t]{2}{*}{$\begin{array}{c}0.3 \mathrm{TWh}+1.95 \mathrm{TWh} \text { from } \\
\text { biomass combustion and } \\
\text { co-incineration }(2019)\end{array}$} \\
\hline Energa CG & $1.38 \mathrm{GWe}$ & $0.575 \mathrm{GW}$ & $18.8 \mathrm{TWh}^{1}$ & 3.2 TWh & $191,000 \mathrm{~km}$ & \\
\hline
\end{tabular}

${ }^{1}$ Including sale of natural gas ${ }^{2}$ Per one track with connections. Source: own study [44-47].

In Poland, around 130,000 people professionally work within the production and supply of the electricity industry (Table 6).

In 2013-2017, the number of employees in this section decreased, while in 2018, it increased slightly. At the same time in 2018, the hiring rate for the first time in the analyzed period exceeded the layoff rate. It is worth noting that the main reason for the dismissals is retirement and disability pensions.

The average monthly salary in this section exceeds the monthly average wage in Poland, and its growth is also faster. Among the factors determining this state is a significant percentage of people employed in this section in conditions of risk of elements harmful and dangerous to health, higher than for all employees in Poland. Work in such situations is compensated with cash benefits.

A unique feature of the energy sector is also the strong position of trade unions, including more than half of the employees. It translates into the indicated relatively stable wage growth and employment guarantees more favorable than in other industries [51]. 
Table 6. Energy section-the context of the labor market.

\begin{tabular}{|c|c|c|c|c|c|c|}
\hline Years & $\begin{array}{c}\text { Employed } \\
\text { Persons in the } \\
\text { Section } \\
\text { "Electricity, } \\
\text { Gas, Steam, } \\
\text { and Hot Water } \\
\text { Production } \\
\text { and Supply" in } \\
\text { Thous. }\end{array}$ & $\begin{array}{l}\text { Hire Rate for } \\
\text { the Section } \\
\text { "Electricity, } \\
\text { Gas, Steam } \\
\text { and Hot Water } \\
\text { Supply" in } \% 1\end{array}$ & $\begin{array}{l}\text { Termination } \\
\text { Rate for the } \\
\text { Section } \\
\text { “Electricity, } \\
\text { Gas, Steam } \\
\text { and Hot Water } \\
\text { Supply" in } \% 2\end{array}$ & $\begin{array}{c}\text { Average } \\
\text { Monthly Total } \\
\text { Gross } \\
\text { Remuneration } \\
\text { in PLN }\end{array}$ & $\begin{array}{c}\text { Average Monthly } \\
\text { Gross } \\
\text { Remuneration in } \\
\text { the Section } \\
\text { "Electricity, Gas, } \\
\text { Steam and Hot } \\
\text { Water Generation } \\
\text { and Supply" in } \\
\text { PLN }\end{array}$ & $\begin{array}{c}\text { Employed in } \\
\text { Conditions of Risk } \\
\text { of Harmful and } \\
\text { Hazardous Factors } \\
\text { in the Section } \\
\text { "Electricity, Gas, } \\
\text { Steam and Hot } \\
\text { Water Supply" } \\
\text { in \% }{ }^{2}\end{array}$ \\
\hline 2013 & 137.3 & 14.4 & 17.9 & 3659.40 & 6234.55 & 38.7 \\
\hline 2014 & 130.5 & 8.0 & 12.8 & 3777.10 & 6353.66 & 18.3 \\
\hline 2015 & 125.2 & 4.6 & 8.6 & 3907.85 & 6546.95 & 19.6 \\
\hline 2016 & 123.2 & 5.7 & 7.3 & 4052.19 & 6763.53 & 13.9 \\
\hline 2017 & 122.5 & 7.4 & 8.5 & 4283.73 & 7015.03 & 14.3 \\
\hline 2018 & 124.1 & 10.6 & 9.3 & 4589.91 & 7423.42 & 14.5 \\
\hline
\end{tabular}

1 "The hire rate is calculated as the ratio of the number of hires less the number of persons returning to work from child-care leaves during a surveyed year to the number of full-time paid employees as of 31 December from the year preceding the surveyed year" [48]. 2 "The termination rate is calculated as the ratio or the number of terminations less the number of persons granted child-care leaves during a surveyed year to the number of full-time paid employees as of 31 December from the year preceding the surveyed year" [48]. Source: own study based on [48-50].

As shown in Table 7, the energy potential of individual entities operating in the section, including the analyzed capital groups, is related to their human resources.

Table 7. Human resources in the leading capital groups generating electricity in Poland in the year 2019.

\begin{tabular}{|c|c|c|c|c|}
\hline Company & $\begin{array}{l}\text { The Total Number of } \\
\text { Employees Under an } \\
\text { Employment Contract }\end{array}$ & $\begin{array}{l}\text { Total Number of } \\
\text { Newly Hired } \\
\text { Employees }{ }^{1}\end{array}$ & $\begin{array}{c}\text { Total Number of } \\
\text { Employees Who Left } \\
\text { Their Jobs }\end{array}$ & $\begin{array}{c}\text { Average Number of } \\
\text { Training Days/Hours per } \\
\text { Employee }\end{array}$ \\
\hline PGE CG & 42,280 & 3040 & 2711 & 2.2 days \\
\hline TAURON CG & 26,086 & 1723 & $\mathrm{n} / \mathrm{a}$ & $18 \mathrm{~h}$ \\
\hline ENEA CG & 17,291 & 2016 & 1254 & $\begin{array}{l}\text { Depending on the company, } \\
3-35 \mathrm{~h} \text { per employee-woman, } \\
8-33 \mathrm{~h} \text { per employee-man }\end{array}$ \\
\hline Energa CG & 10,124 & 977 & 633 & $17 \mathrm{~h}$ \\
\hline
\end{tabular}

${ }^{1}$ Employees who leave the organization voluntarily or due to dismissal, retirement, or death during employment in 2019. Source: own study based on [44-47].

The previously mentioned capital groups include entities conducting business activities related mainly to the generation and distribution of electricity, although their additional activities are associated with other sectors of the economy, such as administration services and supporting activities, an example of which is the Energa Capital Group (Table 8).

Therefore, seeing the strategic and economic potential, it is worth paying attention to the competencies that people employed in the energy sector should have at their disposal. The diagnosis of employer expectations in this respect seems to be particularly important from the point of view of challenges and changes that will be subject to the energy sector in Poland and the world in the near future. 
Table 8. Entity structure of leading capital groups.

\begin{tabular}{cl}
\hline Company & \multicolumn{1}{c}{ Companies Included in the Capital Group } \\
\hline \multirow{3}{*}{ PGE CG } & PGE Energia Odnawialna SA, PGE Obrót SA, PGE Systemy SA, PGE Dom Maklerski SA, PGE Dystrybucja SA, \\
& PGE GIEK SA, PGE Ventures sp. z o.o., TFI Energia SA, PGE Energia Ciepła SA, Lumi-PGE Centrum sp. z o.o., \\
& PGE Baltica sp. z o.o., PGE Foundation \\
& TAURON Wydobycie SA, TAURON Wytwarzanie SA, TAURON Dystrybucja SA, TAURON Ciepło sp. z o.o., \\
& TAURON Ekoenergia sp. z o.o., TAURON Obsługa Klienta sp. z o.o., TAURON Sprzedaż sp. z o.o., TAURON \\
& Czech Energy sro, Limestone Mine Chatkowice sp. z o.o., Polish Energy-First Trading Company sp. z o.o., \\
TAURON CG & TAURON Nowe Technologie SA, TAURON Sprzedaż GZE sp. z o.o., TAURON Dystrybucja Pomiary sp. z o.o., \\
& TAURON Serwis sp. z o.o., Support for Grupa TAURON sp. z o.o., Bioeko Grupa TAURON sp. z o.o., TAURON \\
& Ubezpieczenia sp. z o.o., Nowe Jaworzno Grupa TAURON sp. z o.o. \\
& Enea SA, Enea Operator, Enea Wytwarzanie, Enea Połaniec, Enea Centrum, Enea Warm, Enea Ciepło Serwis, \\
& Enea Innovations, E nea Logistics, Enea New Energy, Enea Lighting, Enea Measurements, Enea Serwis, Enea \\
& Trading, Lubelski Wegiel Bogdanka SA \\
& Energa Operator, Contractor Elektroenergetyczne sp. z o.o., Energa Obrót SA, Energa Lighting sp. z o.o.,, \\
& Enspirion sp. z o.o., Energa Slovakia sro, Energa OZE SA, Energa Elektrownie Ostrołęka SA, Energa Kogeneracja \\
& sp. z o.o., Energa Serwis sp. z o.o., Energa Ciepło Kaliskie sp. z o.o., Energa Ciepło Ostrołeka sp. z o.o., CCGT \\
& Grudziadz sp. z o.o., CCGT Gdańsk sp. z o.o., Energa SA, Energa Finance AB, Energa Informatyka i Technologie \\
& sp. z o.o., Energa Centrum Usług Wspólnych sp. z o.o., Energa Invest sp. z o.o., Energa Logistyka sp. z o.o., \\
& Energa Ochrony sp. z o.o., Research and Development Center for them. M. Faradaya sp. z o.o., ECARB sp. z o.o. \\
\hline
\end{tabular}

Source: own study based on [44-47].

\section{Directions of Strategic Development of the Energy Market in Poland versus Expectations in Terms of Employee Competencies}

The conventional energy system is undergoing transformation due to decentralization, electrification, and digitalization, which create new opportunities for the integration of renewable energy sources into the global energy market [52]. Renewable energies are essential in the transition towards a climate-neutral economy, contributing to the decarbonization needed to combat climate change [53]. The renewable energy sector is developing rapidly through the use of intelligent technologies such as Big Data, Digital Twin (DT), the Internet of Things (IoT), or Artificial Intelligence (AI). These digital technologies enable renewable energy companies to significantly improve their operations [54,55]. Empirical studies indicate that innovative technologies, especially digitization tools, are crucial in creating the right solutions for energy efficiency [56]. To adapt the renewable energy sector to the challenges of the digital revolution, human resources need to be digitally competent and able to successfully implement digital technologies $[52,57]$.

It is worth emphasizing that the digital revolution is changing the nature of work and competency requirements in the energy sector [58-60]. As the energy sector faces digital transformation [10,61-63], it also requires digital transformation competencies, especially: digital technology orientation and adoption, analytical skills, industry-specific analytics, process improvement and digitalization, digital technology expertise, analytical skills, data management, portfolio management, agile project management [61], and good skills in virtual communication [10]. Desirable competencies include, among others: basic data processing, basic digital skills, programming, advanced Information Technology (IT), advanced data analysis, data management-safe storage, and use of digital communication tools [64]. In the energy industry, it is also required a broad know-how base of electricity, automation technology, and the production of electricity. Sales competencies and financial literacy are also desirable $[65,66]$. The competencies required in the energy sector also include monitoring systems of energy consumption, sustainable resource management, waste reduction and waste management, knowledge and understanding of international and national standards and legislation, product life cycle impact assessment, climate change risk management, and environmental awareness [64] as well as print reading, project planning, development of short- and long-term plans and supervisory skills [67]. It is worth highlighting that the required competencies due to the digital revolution involve both technical and economic competencies [52,65]. 
Global energy demand is growing worldwide in both developing and developed countries [68,69]. Energy companies are facing new challenges as the growing demand for energy cannot be supplied predominantly from fossil energy sources as today due to the progressive climate change. Therefore, the energy sector is focused on the transition from fossil fuels, which are limited and negatively affect the state of the natural environment, to clean energy [70,71]. Recently, many technologies have been discovered or improved that can significantly reduce greenhouse gas emissions, such as renewable or low-carbon energy generation installations, advanced energy storage systems, or carbon capture devices [72]. Applying more renewables reducing carbon dioxide emissions, and increasing energy efficiency as well as introducing smart grids create new opportunities for energy companies to operate and develop [73,74].

Consequently, energy companies need to be innovative and have highly qualified employees to keep up with the growing demand for energy and contemporary challenges $[74,75]$. Therefore, the competencies required in the energy companies also include soft competencies such as complex problem solving, creativity, innovative thinking, critical thinking, interdisciplinary thinking, decision-making, active listening, teamwork, communication, cultural empathy, entrepreneurship, initiative-taking, opportunity assessment, continuous learning, flexibility, adaptability and adapt to change $[52,57,64,65,76]$. Moreover, in the energy sector, there are required appropriate linguistic skills [64], for example, English and Russian [65]. Other favorable competencies are advanced first aid and rescue, conflict resolution, negotiation skills, customer relationship management, quantitative and statistical skills [64].

Another area to be taken into consideration is that in the energy sector, there is a strong need for a wide range of managerial competency development [10,11,61,77-79]. Among the challenges ahead, there is a need for the competency system to be flexible enough to address a broad range of issues, targets, topics, operation types, as well as a progression of proficiencies (e.g., employee competency development to senior-level positions). There is a need for a system that is practical and can be developed and, if needed, adopted in a relatively short time frame $[77,79]$. Consequently, managerial competencies in the energy sector are required not only for developing a business strategy, goals, and tools for achieving them but also to provide an appropriate organizational culture to internal and external communications and human resource management (selection, motivation, professional growth, and skills advancement) [78]. Researchers indicate new managerial qualities and competencies such as: making strategic decisions based on global trends and multiple-factor risks, organization of innovative processes, management of complex energy projects and programs, cross-disciplinary teamwork, international experience [10].

Key competencies in the energy sector are also those needed for rapid recognition of accidents and, if necessary, accident management [80]. There is also a need for flexibility to respond to the requirements of the energy sector of large-scale adaptive professional competencies and skills that are changing together with the innovative technologies as well as the sustainable resource-friendly use of energy [81].

\section{Materials and Methods}

The paper should be considered as explorative research, conducted with the aim to address three research questions:

1. What are the needs of competencies in the Polish energy labor market?

2. What is the structure of hard skills and soft skills within the labor market demand?

3. Is the trend connected with renewable energy sources visible in labor market demand?

In order to achieve the aim of the article, 245 job advertisements were analyzed. All the offers were posted by the companies in open access on one of the sources: the company website and the job offer portal "Pracuj.pl" which is the biggest and the most popular job offer portal in Poland. Most essential data were copied by the researchers, and all the doubling offers were canceled from the research sample.

The research involves human beings questioning neither personal data. 
For the need of the research, operationalization of variables was conducted: RES, company name, type of the job, level of a position, and required experience.

RES-renewable energy sources-sources of energy that are connected with solar, wind, hydro/water, geothermal, and biomass power.

Company name-research was conducted among four big energy companies in Poland-PGE, Tauron, Enea, and Energa. Energa, as one of the biggest energy companies in Poland in 2020, was starting to merge with ORLEN GROUP, and the merging process is being continued. This is why in many reports, Energy Company is no longer present, but the company is still recruiting under its own name.

Type of the job-job descriptions were divided into two main groups that reflect the two main types of a career in this kind of company: technical employees and administration employees. Technical employees are mainly working with machines and in the field, whereas administration employees are working in the offices.

Level of a position-based on the job advertisements, researchers decided to divide the type of a position into seven categories (as they were declared by the employers). Operational workers, junior positions, middle positions, senior positions, specialist positions, experts, and managerial.

The required experience was counted in years and was declared by the employers.

Particular statistical methods were introduced in the research procedure. There was one qualitative method-the Delphi method-used to group competencies based on specialist knowledge of researchers and to assign groups of competencies into hard or soft skills. For quantitative methods, there were:

1. Shapiro-Wilk test of distribution normality;

2. H Kruskal-Wallis test for comparing more than 2 independent samples;

3. U Mann-Whitney for comparing two independent samples;

4. Spearman's Rho-for correlation check;

5. General descriptive statistics.

All the research and calculations were prepared using SPSS 27 software.

The research sample was collected between 24 May and 7 June 2021. All the job offers were issued by one of the four leading energy companies in Poland: PGE (78 job offers), Tauron ( 87 job offers), Enea (33 job offers), and Energa ( 47 job offers).

\section{Results}

The explorational approach toward the research revealed 153 different competencies that were required by the employers.

Mostly appearing competencies are presented in Table 9. It is essential to state that those are only competencies that had 25 or more indications (which states for $10 \%$ of job offers).

Two competencies: teamwork (51\%) and MS-Office (50\%), were required in half of the researched job offers. Four competencies were required in around 30\%, and those were the organization of work (38\%), communication $(37 \%)$, analytical thinking $(31 \%)$ knowledge of law $(27 \%)$. Team management and computer usage were required in one in ten job offers.

In order to make the analysis much more readable, researchers decided to use the Delphi method to group competencies and continue the study. As the results of the grouping process, eight different groups were presented, those were: IT competencies, electric qualifications, general competencies, intrapersonal, working with machines, working with documents, working with people, and organizational competencies.

The examples of the commonly indicated competencies that are grouped are presented in Table 10. 
Table 9. Most required competencies.

\begin{tabular}{lcc}
\hline \multicolumn{1}{c}{ Competence } & Number of Indications & Percent of Indications \\
\hline Teamwork & 126 & $51 \%$ \\
MSOffice & 123 & $50 \%$ \\
Organization of work & 92 & $38 \%$ \\
Communication & 91 & $37 \%$ \\
Analytical thinking & 77 & $31 \%$ \\
Law & 67 & $27 \%$ \\
Self-reliance & 59 & $24 \%$ \\
English language & 58 & $24 \%$ \\
Accuracy & 58 & $24 \%$ \\
Initiative & 57 & $23 \%$ \\
Ability to develop oneself & 57 & $23 \%$ \\
Time management & 57 & $23 \%$ \\
Electrical qualifications and certificates & 56 & $23 \%$ \\
Goals orientation & 51 & $21 \%$ \\
Technical knowledge & 44 & $18 \%$ \\
Engagement & 42 & $17 \%$ \\
Responsibility & 40 & $16 \%$ \\
IT systems & 40 & $16 \%$ \\
SAP system knowledge & 37 & $15 \%$ \\
Building and maintaining relations with & 35 & $14 \%$ \\
employees and clients & 35 & $14 \%$ \\
Availability & 35 & $14 \%$ \\
Decision making & 29 & $12 \%$ \\
Scrupulousness & 26 & $11 \%$ \\
Working with machines & 25 & $10 \%$ \\
Computer usage & 25 & $10 \%$ \\
Team management & &
\end{tabular}

Source: own study.

Table 10. Competency groups and what is inside.

\begin{tabular}{cll}
\hline Competency Group & \multicolumn{1}{c}{ Competency } & Compentecy \\
\hline & IT system administration & Planning networks \\
& SQL & Online work \\
& AutoCAD & Dedicated software \\
& DCS systems & Coding \\
& LTE monitoring & RPA platforms \\
& MSOffice & SAP \\
& IT Tools usage & UX \\
Electric qualifications & Computer usage & VBA \\
& E1 & SEP \\
& E2 & \\
& Driving license & Thematic qualifications \\
& Curiosity & Creativity \\
& Determination & Decency \\
& Accuracy & Motivations \\
& Availability & Responsibility \\
& Readiness to grow & Punctuality \\
& Initiative & Self-reliance \\
& Building and maintaining relations with & Teamwork \\
& employees and clients & Shift work \\
& Verbal communication & Negotiating \\
& Written communication & \\
\hline
\end{tabular}


Table 10. Cont.

\begin{tabular}{cll}
\hline \multicolumn{1}{c}{ Competency Group } & \multicolumn{1}{c}{ Competency } & \multicolumn{1}{c}{ Compentecy } \\
\hline \multirow{3}{*}{ Organizational competencies } & Methodical management & Project settlement \\
& Prioritizing & Financial knowledge \\
& Budgeting & Management \\
& Technical drawings & Technical documentation \\
\multirow{2}{*}{ Working with documentation } & Creating documents & Protocols \\
& Schemas & \\
& Use of electric machines & Railway license \\
Working with machines & Technology and machine testing & Technical knowledge \\
& Licenses for forklifts and truck equipment & Electric network knowledge \\
\hline
\end{tabular}

Source: own study.

The widest represented group was connected with information technology. There were 16 main competencies that were required by employers. The second-largest group of competencies was the one associated with intrapersonal competencies. It is essential to state that this group was mainly connected with the intrapersonal approach and personal competencies. The third-largest group was connected with working with people and was represented by seven main competencies. Working with people was based on an interpersonal approach and working within the professional environment, and organizational competencies were based on hard management skills and financial knowledge.

There were also six different competencies in the working with machines group that mostly comprise licenses and heavy machinery tasks. The working with documents group was connected with reading, creating, and maintaining all the legal aspects of work. The most minor groups were those associated with electrical qualifications and general competencies. It is crucial to state that those were only examples of competencies that were indicated by employers, but their number reflects the complete structure of those groups.

Each group was firstly assessed by summing the elements in each group. The general results are presented in Table 11.

Table 11. Indications of competencies within the groups. Descriptive Statistics.

\begin{tabular}{lccccc}
\hline \multicolumn{1}{c}{ Competence Group } & N & Minimum & Maximum & Mean & Std. Deviation \\
\hline Intrapersonal & 245 & 0 & 12 & 3.72 & 2.580 \\
IT & 245 & 0 & 6 & 1.32 & 1.144 \\
Working with people & 245 & 0 & 4 & 1.25 & 0.937 \\
Working with machines & 245 & 0 & 6 & 0.99 & 1.313 \\
General competencies & 245 & 0 & 5 & 0.94 & 1.071 \\
Organizational & 245 & 0 & 3 & 0.56 & 0.702 \\
competencies & 245 & 0 & 2 & 0.31 & 0.554 \\
Electric qualifications & 245 & 0 & 2 & 0.13 & 0.365 \\
Working with documents & & & &
\end{tabular}

Source: own study.

As it is visible from Table 9, the average job offer in the field of energy in Poland consists of around nine competencies (based on the sum of means-3.72 intrapersonal competencies, 1.32 IT competencies, 1.25 working with people competencies, 0.99 working with machines competencies, 0.94 general competencies, 0.56 organizational competencies, 0.31 electric qualifications and 0.13 working with documentation competencies), out of which almost four were connected with intrapersonal competencies, there was also competence related to IT, working with people, and working with machines, as well as general competencies. Electric qualifications are required in half of the offers, and working with documents is required in about 1 out of 10 job offers.

In order to describe the labor market in more detail, a number of tests were conducted to search for differences and correlations within four criteria: company, type of job, level of the position, and required experience. As the statistical significance of the Shapiro-Wilk 
normality test for each group was $p<0.001$, non-parametric tools are to be used in the next part of the research.

Criterion 1-Companies require different competencies

In order to check this hypothesis, the H Kruskal-Wallis test was performed. Results are presented in Table 12.

Table 12. Companies and the number of competencies.

\begin{tabular}{lccc}
\hline \multicolumn{1}{c}{ Competence Group } & Kruskal-Wallis H & Df & Asymp. Sig. \\
\hline IT & 2.972 & 3 & 0.396 \\
Electric qualifications & 9.995 & 3 & 0.019 \\
General competency & 23.786 & 3 & 0.000 \\
Intrapersonal & 8.306 & 3 & 0.040 \\
Working with machines & 9.825 & 3 & 0.020 \\
Working with documentation & 7.731 & 3 & 0.052 \\
Working with people & 8.581 & 3 & 0.035 \\
Organizational competencies & 0.416 & 3 & 0.937 \\
\hline
\end{tabular}

Source: own study.

Companies are requiring different competencies within electric qualifications $(\mathrm{H}=9.995$, $p=0.019)$, general competencies $(\mathrm{H}=23.786, p<0.001)$, intrapersonal competencies $(\mathrm{H}=8.306, p=0.04)$, working with machines $(\mathrm{H}=9.825, p=0.02)$, and working with people $(\mathrm{H}=8.581, p=0.035)$.

Criterion 2-Type of differing job competency requirements

In order to check this hypothesis, the U Mann-Whitney test was performed. Results are presented in Table 13.

Table 13. U Mann-Whitney Tests.

\begin{tabular}{lcccc}
\hline \multicolumn{1}{c}{ Competence Group } & Mann-Whitney U & Wilcoxon W & Z & $\begin{array}{c}\text { Asymp. Sig. } \\
\text { (Two-Tailed) }\end{array}$ \\
\hline IT & 6229.000 & $12,334.000$ & -2.257 & 0.024 \\
Electric qualifications & 4290.000 & $13,470.000$ & -7.344 & 0.000 \\
General competency & 3597.500 & $12,777.500$ & -7.395 & 0.000 \\
Intrapersonal & 6312.000 & $12,417.000$ & -2.034 & 0.042 \\
Working with machines & 3166.500 & $12,346.500$ & -8.320 & 0.000 \\
Working with & 7186.000 & $16,366.000$ & -0.752 & 0.452 \\
documentation & 6866.500 & $12,971.500$ & -1.073 & 0.283 \\
Working with people & 4940.000 & $11,045.000$ & -5.063 & 0.000 \\
Organizational & & & & \\
competencies & & &
\end{tabular}

Source: own study.

Employers required administration jobs more $(\mathrm{U}=6229.00, p=0.024)$ IT competencies $(\mathrm{Md}=1)$, less $(\mathrm{U}=4290.00, p<0.001)$, electric qualifications $(\mathrm{Md}=0.0)$ and also less $(\mathrm{U}=3597.50, p<0.001)$ general competencies; $(\mathrm{Md}=0.0)$, more $(\mathrm{U}=6229.00, p=0.024)$ intrapersonal competencies $(\mathrm{Md}=4)$ and more $(\mathrm{U}=6229.00, p=0.024)$ organizational competencies $(\mathrm{Md}=1)$ than for technical positions $(\mathrm{Md}=1,0.5 ; 1 ; 3 ; 0)$, respectively.

Criterion 3-Level of position differ employer requirements.

In order to check this hypothesis, the H Kruskal-Wallis test was performed. Results are presented in Table 14. 
Table 14. Levels of a position.

\begin{tabular}{lccc}
\hline \multicolumn{1}{c}{ Competence Group } & Kruskal-Wallis H & Df & Asymp. Sig. \\
\hline IT & 20.718 & 5 & 0.001 \\
Electric qualifications & 55.256 & 5 & 0.000 \\
General competency & 51.660 & 5 & 0.000 \\
Intrapersonal & 8.274 & 5 & 0.142 \\
Working with machines & 50.814 & 5 & 0.000 \\
Working with documentation & 9.976 & 5 & 0.076 \\
Working with people & 19.733 & 5 & 0.001 \\
Organizational competencies & 42.007 & 5 & 0.000 \\
\hline
\end{tabular}

Source: own study.

The level of a position differs from the competence requirements, but it is important to state that those are operational workers who have the results of the U Mann-Whitney test statistically significant in comparison with other levels and based on results $(p<0.001$ or close to that level) are responsible for all variability.

Criterion 4-Required experience is correlated with the number of required competencies.

In order to check this hypothesis, Spearman's rho test was conducted. Results are presented in Table 15.

Table 15. Correlation between experience and the number of required competencies.

\begin{tabular}{lcc}
\hline \multicolumn{1}{c}{ Competence Group } & Spearman's rho Experience (in Years) & $p$ \\
\hline IT & 0.105 & 0.107 \\
Electric qualifications & -0.283 & 0.000 \\
General competency & -0.199 & 0.009 \\
Intrapersonal & 0.068 & 0.209 \\
Working with machines & -0.145 & 0.043 \\
Working with documentation & -0.110 & 0.096 \\
Working with people & 0.003 & 0.488 \\
Organizational competencies & 0.268 & 0.001 \\
\hline
\end{tabular}

Source: own study.

There was a statistically significant negative correlation between the experience and electrical qualifications ( $\mathrm{rs}=-0.283, p=0.000)$, general competencies ( $\mathrm{rs}=-0.199, p=0.009$ ) and working with machines ( $\mathrm{rs}=-0.145, p=0.043$ ), as well as positive correlation with organizational competencies ( $\mathrm{rs}=-0.268, p=0.001)$. It is worth mentioning that all the correlations were rather weak.

The second research question was connected with hard skills and soft skills and their structure on the labor market of energy companies in Poland. Researchers decided to use the Delphi method to assign previously acquired competency groups into hard and soft skills and to sum up all of the required competencies. There were two competency groups that were assigned to soft skills, and those were intrapersonal and working with people competencies. Six others were grouped as hard skills, and those are IT, working with machines, general competencies, organizational competencies, electric qualifications, and working with documentation. It was in the researchers' best interest to describe the broad group firstly and later to focus on two types of jobs-technical and administration. The descriptive statistics of hard and soft skills are presented in Table 16.

Table 16. Descriptive statistics of hard and soft skills.

\begin{tabular}{lcccccccc}
\hline & & & & & & \multicolumn{3}{c}{ Percentiles } \\
\cline { 6 - 9 } & N & Mean & $\begin{array}{c}\text { Std. } \\
\text { Deviation }\end{array}$ & Minimum & Maximum & 25th & $\begin{array}{c}\text { 50th } \\
\text { (Median) }\end{array}$ & 75th \\
\hline Hard & 245 & 4.26 & 2.856 & 0 & 14 & 2.00 & 4.00 & 6.00 \\
Soft & 245 & 4.97 & 3.264 & 0 & 14 & 2.50 & 5.00 & 7.00 \\
\hline \multicolumn{2}{l}{ Source: own study. }
\end{tabular}


Soft skills are required more often $(\mathrm{M}=4.97, \mathrm{SD}=3.264, \mathrm{Md}=5)$ than hard skills $(\mathrm{M}=4.26, \mathrm{SD}=2.856, \mathrm{Md}=4)$ in the general group. It is also confirmed by the Wilcoxon test results $\mathrm{T}=1417, \mathrm{z}=-2.616, p=0.009$.

For technical positions, only the descriptive statistics are presented in Table 17.

Table 17. Descriptive statistics of hard and soft skills within technical positions only.

\begin{tabular}{lcccccccc}
\hline & & & & & & \multicolumn{3}{c}{ Percentiles } \\
\cline { 7 - 9 } & N & Mean & $\begin{array}{c}\text { Std. } \\
\text { Deviation }\end{array}$ & Minimum & Maximum & 25th & $\begin{array}{c}\text { 50th } \\
\text { (Median) }\end{array}$ & 75th \\
\hline Hard & 110 & 5.48 & 3.016 & 0 & 14 & 3.75 & 5.00 & 7.00 \\
Soft & 110 & 4.48 & 2.811 & 0 & 13 & 2.00 & 4.00 & 6.00 \\
\hline Source: own study.
\end{tabular}

It is important to state that within technical positions only, Hard skills were required more often $(\mathrm{M}=5.48, \mathrm{SD}=3.016, \mathrm{Md}=5)$ than soft skills $(\mathrm{M}=4.48, \mathrm{SD}=2.811, \mathrm{Md}=4)$ in the technical group. It was also confirmed by the Wilcoxon test results $\mathrm{T}=1757, \mathrm{z}=-2.514$, $p=0.012$.

For administrative positions, only the descriptive statistics are presented in Table 18.

Table 18. Descriptive statistics of hard and soft skills within administrative positions only.

\begin{tabular}{lcccccccc}
\hline & & \multirow{2}{*}{ N } & Mean & $\begin{array}{c}\text { Std. } \\
\text { Deviation }\end{array}$ & Minimum & & \multicolumn{3}{c}{ Percentiles } \\
\cline { 6 - 9 } & & & & Maximum & 25th & $\begin{array}{c}\text { 50th } \\
\text { (Median) }\end{array}$ & 75th \\
\hline Hard & 135 & 3.26 & 2.285 & 0 & 11 & 2.00 & 3.00 & 4.00 \\
Soft & 135 & 5.37 & 3.551 & 0 & 14 & 3.00 & 6.00 & 8.00 \\
\hline \multicolumn{2}{l}{ Source: own study. }
\end{tabular}

It was possible to state that within administrative positions only, soft skills are required more often $(\mathrm{M}=5.37, \mathrm{SD}=3.551, \mathrm{Md}=6)$ than hard skills $(\mathrm{M}=3.26, \mathrm{SD}=2.285, \mathrm{Md}=3)$ in the administration group. It was also confirmed by the Wilcoxon test results $\mathrm{T}=5509$, $\mathrm{z}=-5.613, p<0.001$.

The third research question was connected with the trend of fast-developing renewable energy sources. It was in the researchers' interest to check whether the trend is also visible within job offers on the labor market. It was achieved by describing RES-related positions, which are posts in which RES-related tasks are listed in a job description and RES-related companies, as each of four energy groups in Poland has at least one subsidiary connected with renewable energy sources. The results of a cross-tabulation of RES-related companies and positions are presented in Table 19.

As it is presented in Table 17, the number of positions related to RES was equal to 9 out of 244 positions. It stands for $3.7 \%$ of all job offers. As it is for RES-related companies, there are 19 offers from those companies out of 244 in total, which stands for $7.8 \%$ of the total number of offers. Only four positions related to RES are within the RES-related companies.

Table 19. Descriptive statistics of hard and soft skills within administrative positions only.

\begin{tabular}{|c|c|c|c|c|}
\hline & & \multicolumn{2}{|c|}{ RES Position } & \multirow[t]{2}{*}{ Total } \\
\hline & & No & Yes & \\
\hline \multirow{2}{*}{ RES Company } & No & 220 & 5 & 225 \\
\hline & Yes & 15 & 4 & 19 \\
\hline \multicolumn{2}{|c|}{ Total } & 235 & 9 & 244 \\
\hline
\end{tabular}

Source: own study.

\section{Discussion and Conclusions}

The discussion part is divided into three sections, based on each of the research questions. 
Teamwork was a vital competence in $51 \%$ of job offers. As employees are expected to work more collaboratively than ever before [82], teamwork has a significant effect on organizational performance [83]. Teamwork competence is one of the most important in the energy sector, mainly due to the inter-dependability of employees' tasks as well as to the need for performance adaptation to emerging situational characteristics [84]. Teamwork not only allows teams to produce outcomes greater than the sum of individual member contributions [85] but also influences safe and efficient task performance, which is crucial in the energy sector $[10,84]$. Although teamwork is frequently regulated by procedures and routines, the level of details with which teamwork is described still varies substantially [84]. Despite the increased expectations of working collaboratively and the benefits associated with effective teamwork, companies continue to report a lack of team competencies among their employees [85]. The research results show that this competency is the most desired by employers in the Polish labor market in the energy sector.

As digitalization is a widely described topic [52,86,87], it is perfectly understandable that in $50 \%$ of job offers, knowledge and usage of MS Office and other back-office software are required.

The organization of work (38\%), as well as analytical thinking (31\%), are important as the energy sector is known for its potential need for rapid recognition of accidents and accident management [80]. It implies that every worker should know what to do not only when the job goes smoothly but also when working under pressure.

It is highlighted that not only the abovementioned teamwork but also communication influences organizational performance [88] and plays an important role in the energy sector [89]. It is also worth emphasizing virtual communication as well [10]. It is also underlined that in the energy sector, communication needs master level and that especially during emergencies, there is a distinct need to uphold continuous communication among teammates during complex and/or stressful situations to promote collective sense-making processes and the provision of mutual support [84].

It is also easily visible that the competencies required by employers in Poland are connected and consistent with global trends. These include the most popular intrapersonal skills [57,65,76], IT skills [64], and working with people [67].

There are four main companies in the labor market, and they present different attitudes towards the competency needed; and as a labor market is not homogenous in the context of competency needs, candidates with diverse profiles may apply and successfully get the job. In fact, energy companies are very flexible when it comes to competency needs, as they require employees on every level and type of position.

Describing both technical and administrative job offers, it is important to emphasize that there was no difference in teamwork and working with documentation. It may be explained with the context of nowadays tasks-most of them, no matter on which type of position require teamwork, no matter if it is a technical problem with wires or administration procedures. It is strongly visible in vocational training [90,91]. It is also important to state that administrative jobs require more IT, intrapersonal and organizational competencies, whether technical ones are in need of electric, general, and working with machines competencies.

The researchers noted with interest that there is a correlation between the experience (measured in years) and the number of competencies required by employees. When it comes to general competency, working with electricity, and working with machines, there is a negative correlation. It may be explained by the level of specialization. In order to be able to effectively cope with various situations while working with electric wires or specific machines, it requires considerable time to be able to work effectively. That is why employers require longer experience and, at the same time, not that many competencies connected with electricity or specific, especially technical jobs. The opposite situation is visible when it comes to various organizational competencies. Although they are also assigned as hard skills, the specificity of project work requires a flexible approach and the ability to react correctly in various situations, for example, connected with imperfect 
quality items [92]. That is why when it comes to organizational competencies groups, with the increase in experience, employers require more varied competencies.

Hard and soft skills results may be described as not surprising. Soft skills are generally more demanded than hard skills [93], but when we focus on technical and administrative positions, we would be able to state that when it comes to technical jobs, they require more hard skills. It is easily visible while analyzing job descriptions-where most of the tasks are machine-oriented or technology-oriented. The opposite situation is with administrative positions, where most job description requirements are connected with intrapersonal and communication competence.

Results concerning renewable energy sources might be a point of interest for both scientists and practitioners. While the trend of implementing RES is easily visible all over the world: in western Europe [94], Russia [95], South Asia [96], Brazil [97], and the USA [98], the competency needs do not support this trend in Poland. According to the report made by Jedra [99], almost $17.7 \%$ of electric energy is produced from RES, but the structure of analyzed job offers points to only $3.7 \%$ when it comes to the job descriptions and $7.8 \%$ when it comes to companies. It is a sign that companies do not need a workforce specialized in RES or that subsidiary companies are not that important in the holding structures.

Study results allow presenting practical implications that can be divided into three groups: education, employers, and potential employees.

Not only higher education institutions may benefit from the study. Those are also vocational education institutions that should take into consideration the above-presented results. What is important, the research results indicate that even for technical jobs, soft skills are still highly required. That is why the most important soft competencies such as teamwork, organization of work, communication as well as the hard one-in the area of IT and digitalization - should be developed not only during deliberate study programs but also throughout whole education. It is also advised to implement a more innovative approach of one-to-one work with students in the form of career/ vocational counseling. The abovementioned soft skills require much more time and effort to be acquired by each person than the hard skills. That is why soft skills education should be implemented as soon as possible. Even not only within vocational education but even primary one. This can be achieved when both-companies and education institutions-decide on cooperation and dialog. This can also be achieved when taking into consideration not only formal education but also non-formal and semi-formal activities toward social and environmental challenges, which, as described, are observed in the Polish energy sector.

For the employers, all the required actions should be connected with HRM. On the level of job analyzing processes, the directions of strategic development of the energy market in Poland must be introduced. It seems that Polish employers of the energy sector should pay more attention and appreciation to such competencies as responsibility, initiative, and decision making (only initiative is in the first ten most expected competencies in the research results) as there is a great need for Polish energy sector development and adjustment to the global decarbonization process. The abovementioned competencies may be helpful in making changes in the Polish energy sector in this area.

Recruitment and selection processes should be focused not only on hard skills but also soft skills (for every job position) listed in the research results. Those are especially: teamwork, communication, analytical thinking, and self-reliance. Processes of personnel development should also be focused on those competencies.

It seems to be a need of a current labor market to adjust salary, compensation, and benefits processes to the one based on competencies.

The last perspective that should be considered while discussing the practical implications of the presented study is connected with future prospective employees. The results may be considered as a "road sign" for how to develop competencies and, as such, work on their personal employability.

The conducted research is subjected to various limitations. The most important limitation is that the data were collected only within a period of two weeks. It is subjected 
to a bias of representativeness. Technology cycles or internal procedures may determine the time of recruitment for various positions.

There was a lack of triangulation within the data collection procedure. The data comes from public recruitment sources, whereas some of the processes might be conducted inside the organizations or with the help of head-hunters or outsourcing companies.

As for future research, the topic might be expanded in various ways. From the perspective of methodology, it would be good to conduct longitudinal research to search for trends on the market, as well as triangulation in both data collection and stronger triangulation of data analysis. From the substantive point of view, it is interesting to describe why the importance of RES is not visible in the labor market and to describe and compare countries of a Central Eastern Europe region by conducting a comparative study.

Author Contributions: Conceptualization, M.T. and R.S.; methodology, R.S.; software, R.S.; validation, R.S.; formal analysis, R.S; investigation, R.S., S.W., A.D. and M.K.; resources, M.T, U.B., A.D., S.W., M.K. and R.S.; data curation, R.S.; writing-original draft preparation, M.T., U.B., A.D., S.W., M.K. and R.S.; writing - review and editing, R.S. and S.W.; supervision, M.T. All authors have read and agreed to the published version of the manuscript.

Funding: "The research received financing from an internal program from the Cracow University of Economics: "Doskonałość Naukowa" for the Department of Labor Resource Management.

Data Availability Statement: The data presented in this study are available on request from the corresponding author. The data are not publicly available due to the in-progress work on another paper with this data.

Conflicts of Interest: The authors declare no conflict of interest.

\section{References}

1. Wærness, E. Energy Perspecive; Statoil: Stavanger, Norway, 2012.

2. UNCTAD. World Investment Raport; UN: Geneva, Switzerland, 2012.

3. Czako, V. Employment in the Energy Sector; Publications Office of the EU: Luxembourg, 2020; ISBN 978-92-76-18206-1. [CrossRef]

4. Andrei, M.; Thollander, P.; Pierre, J.; Gindroz, B.; Rohdin, P. Decarbonization of industry: Guidelines towards a harmonized energy efficiency policy program impact evaluation methodology. Energy Rep. 2021, 7, 1385-1398. [CrossRef]

5. Jaworski, J.; Czerwonka, L. Determinants of Enterprises' Capital Structure in Energy Industry: Evidence from European Union. Energies 2021, 14, 1871. [CrossRef]

6. Bogdanov, D.; Gulagi, A.; Fasihi, M.; Breyer, C. Full energy sector transition towards 100\% renewable energy supply: Integrating power, heat, transport and industry sectors including desalination. Appl. Energy 2021, 283. [CrossRef]

7. Saheb, Y.; Ossenbrink, H. Securing energy efficiency to secure the energy union. In How Energy Efficiency Meets the EU Climate and Energy Goals; European Commission Joint Research Centre: Luxembourg, 2015.

8. Starzycka, A.; Młynarczyk, M.; Zdanowski, A. Węgiel Kamienny. Państwowy Instytut Geologiczny; Państwowy Instytut Badawczy: Warszawa, Poland, 2020.

9. Gorevaya, E.S.; Gorevoy, D.V. Analysis of promising business models in solar energy market. In Proceedings of the 13th International Scientific-Technical Conference on Actual Problems of Electronic Instrument Engineering (APEIE), Novosibirsk, Russia, 3-6 October 2016; pp. 227-231. [CrossRef]

10. Gitelman, L.D.; Gitelman, L.M.; Kozhevnikov, M.V. Managers for sustainable electric power industry of tomorrow. Int. J. Sustain Dev. Plan. 2018, 13, 307-315. [CrossRef]

11. Gitelman, L.D.; Sandler, D.G.; Gavrilova, T.B.; Kozhevnikov, M.V. Complex systems management competency for technology modernization. Int. J. Des. Nat. Ecodynamics 2017, 12, 525-537. [CrossRef]

12. White, R. Motivation reconsidered: The Concept of competence. Psychol. Rev. 1959, 66, 297. [CrossRef] [PubMed]

13. McClelland, D.C. Testing for competence rather than intelligence. Am. Psychol. 1973, 28, 1-14. [CrossRef] [PubMed]

14. Boyatzis, R.E. The Competent Manager: A Model for Effective Performance; John Wiley \& Sons: New York, NY, USA, 1982.

15. Young, M. National vocational qualifications in the United Kingdom: Their origins and legacy. J. Educ. Work 2011, 24, 259-282. [CrossRef]

16. Brophy, M.; Kiely, T. Competencies: A new sector. J. Eur. Ind. Train. 2002, 26, 165-176. [CrossRef]

17. Spencer, L.M.; Spencer, S.M. Competence at Work: Models for Superior Performance; John Wiley \& Sons: New York, NY, USA, 1993.

18. Thierry, D.; Sauret, C.; Monod, N. Zatrudnienie i Kompetencje w Przedsiębiorstwach w Procesach Zmian; Poltext: Warszawa, Poland, 1994.

19. Levy-Leboyer, C. Kierowanie Kompetencjami. Bilans Doświadczeń Zawodowych; Poltext: Warszawa, Poland, 1997.

20. Dubois, D.D.; Rothwell, W.J. Zarzadzanie Zasobami Ludzkimi Oparte na Kompetencjach; Helion: Gliwice, Poland, 2008. 
21. Armstrong, M. Armstrong's Handbook of Human Resource Management Practice; Kogan Page Business Books: London, UK, 2009.

22. Becker, B.E.; Huselid, M.A.; Ulrich, D. The HR Scorecard: Linking People, Strategy, and Performance; HBS Press: Boston, MA, USA, 2001.

23. Whiddett, S.; Hollyforde, S. A Practical Guide to Competencies; Chartered Institute of Personnel \& Development: London, UK, 2003.

24. Mansfield, B. What is "competence" all about? Competency 1999, 6, $24-28$.

25. Cheetham, G.; Chivers, G. The reflective (and competent) practitioner: A model of professional competence which seeks to harmonise the reflective practitioner and competence-based approaches. J. Eur. Ind. Train. 1998, 22, 267-276. [CrossRef]

26. Boyatzis, R.E. Competencies in the 21st century. J. Manag. Dev. 2008, 27, 5-12. [CrossRef]

27. Gholipur, R.A.; Mahmoodi, S.M.; Jandaghi, G.; Fardmanesh, H. Presentation Model of Managerial Competency Approach in Management Development. Interdiscip. J. Contemp. Res. Bus. 2012, 3.

28. Sisson, L.G.; Adams, A.R. Essential Hospitality Management Competencies: The Importance of Soft Skills. J. Hosp. Tour. Educ. 2013, 25, 131-145. [CrossRef]

29. Dixon, J.; Belnap, C.; Albrecht, C.; Lee, K. The importance of soft skills. Corp. Financ. Rev. 2010, 14, 35-38.

30. Weber, M.R.; Finely, D.A.; Crawford, A.; Rivera, D.J. An exploratory study identifying soft skill competencies in entry-level managers. Tour. Hosp. Res. 2009, 9, 353-361. [CrossRef]

31. Anthony, S.; Garner, B. Teaching Soft Skills to Business Students: An Analysis of Multiple Pedagogical Methods. Bus. Commun. Q. 2016, 79, 360-370. [CrossRef]

32. Robles, M.M. Executive perceptions of the top 10 soft skills needed in today's workplace. Bus. Commun. Q. 2012, 75, 453-465. [CrossRef]

33. Marques, J. Understanding the strength of gentleness: Soft-skilled leadership on the rise. J. Bus. Ethics 2013, 116, 163-171. [CrossRef]

34. Vandana, S.S.R.; Yadav, D.; Sarkar, B.; Sarkar, M. Impact of Energy and Carbon Emission of a Supply Chain Management with Two-Level Trade-Credit Policy. Energies 2021, 14, 1569. [CrossRef]

35. Energy Law from April 10, 1997 (Journal of Laws No. 54, Item 348, as Amended). Available online: https:// isap.sejm.gov.pl/isap. nsf/download.xsp/WDU19970540348/U/D19970348Lj.pdf (accessed on 1 September 2021).

36. Energy Sector in Poland, Polish Information and Foreign Investment Agency. Available online: http:/ / www.paih.gov.pl (accessed on 25 August 2021).

37. Report on the activities of the President of the ERO 2011, p.21. Available online: https://www.ure.gov.pl/pl/urzad/informacjeogolne/aktualnosci/4258,Raport-Krajowy-2011-Prezesa-URE-dla-Komisji-Europejskiej.html (accessed on 1 September 2021).

38. Główny Urząd Statystyczny. Statistical Yearbook of the Republic of Poland 2013; Zakład Wydawnictw Statystycznych: Warsaw, Poland, 2013. Available online: https://stat.gov.pl/files/gfx/portalinformacyjny/en/defaultaktualnosci/3328/2/8/1/rs_ rocznik_statystyczny_rp_2013.pdf (accessed on 27 October 2021).

39. Główny Urząd Statystyczny. Statistical Yearbook of the Republic of Poland 2015; Zakład Wydawnictw Statystycznych: Warsaw, Poland, 2015. Available online: https://stat.gov.pl/files/gfx/portalinformacyjny/en/defaultaktualnosci/3328/2/10/1/publ_ as_statistical_yearbook_of_the_rep_of_poland.pdf (accessed on 27 October 2021).

40. Główny Urząd Statystyczny. Statistical Yearbook of the Republic of Poland 2018; Zakład Wydawnictw Statystycznych: Warsaw, Poland, 2018. Available online: https://stat.gov.pl/en/topics/statistical-yearbooks/statistical-yearbooks/statistical-yearbookof-the-republic-of-poland-2018,2,19.html (accessed on 27 October 2021).

41. Główny Urząd Statystyczny. Statistical Yearbook of the Republic of Poland 2020; Zakład Wydawnictw Statystycznych: Warsaw, Poland, 2020. Available online: https://stat.gov.pl/en/topics/statistical-yearbooks/statistical-yearbooks/statistical-yearbookof-the-republic-of-poland-2020,2,22.html (accessed on 27 October 2021).

42. Enerdata. Poland Energy Report; Enerdata: Grenoble, France, 2012.

43. Urząd Regulacji Energetyki. Charakterystyka Rynku Energii Elektrycznej. Available online: https://www.ure.gov.pl (accessed on 6 August 2021).

44. PGE Polska Grupa Energetyczna. Available online: https://www.gkpge.pl (accessed on 1 September 2021).

45. Tauron Polska Energia. Available online: https://www.tauron.pl (accessed on 30 August 2021).

46. Enea. Available online: https://www.enea.pl/ (accessed on 1 September 2021).

47. Grupa Energa. Available online: https://grupa.energa.pl/ (accessed on 31 August 2021).

48. Główny Urząd Statystyczny. Yearbook of Labour Statistics 2019; Zakład Wydawnictw Statystycznych: Warsaw, Poland, 2019.

49. Główny Urząd Statystyczny. Yearbook of Labour Statistics 2015; Zakład Wydawnictw Statystycznych: Warsaw, Poland, 2015.

50. Główny Urząd Statystyczny. Yearbook of Labour Statistics 2017; Zakład Wydawnictw Statystycznych: Warsaw, Poland, 2017.

51. Earnings and Work in the Energy Sector. CIRE: Polska. 2011. Available online: https://www.cire.pl/artykuly/materialyproblemowe/61259-raport-cire-zarobki-i-praca-w-energetyce (accessed on 1 September 2021).

52. Arcelay, I.; Goti, A.; Oyarbide-Zubillaga, A.; Akyazi, T.; Alberdi, E.; Garcia-Bringas, P. Definition of the future skills needs of job profiles in the renewable energy sector. Energies 2021, 14, 2609. [CrossRef]

53. Ilzarbe, J.M.B.; Gonzalez, J.C.R. Energy and climate change in the post-covid-19 scenario. DYNA Ing. E Ind. 2020, 95, 570-571.

54. Borowski, P.F. Digitization, digital twins, blockchain, and industry 4.0 as elements of management process in enterprises in the energy sector. Energies 2021, 14, 1885. [CrossRef] 
55. Onile, A.E.; Machlev, R.; Petlenkov, E.; Levron, Y.; Belikov, J. Uses of the digital twins concept for energy services, intelligent recommendation systems, and demand-side management: A review. Energy Rep. 2021, 7, 997-1015. [CrossRef]

56. Habibi, S. Micro-climatization and real-time digitalization effects on energy efficiency based on user behaviour. Build Environ. 2017, 114, 410-428. [CrossRef]

57. Kuo, C.-G.; Chang, C.-C. Building professional competencies indices in the solar energy industry for the engineering education curriculum. Int. J. Photoenergy 2014, 2014, 963291. [CrossRef]

58. Gonzalez Vazquez, I.; Milasi, S.; Carretero Gomez, S.; Napierala, J.; Robledo Bottcher, N. The Changing Nature of Work and Skills in the Digital Age; Publications Office of the EU: Brussels, Belgium, 2019; ISBN 978-92-76-09206-3.

59. Borowski, P.F. Zonal and nodal models of energy market in European Union. Energies 2020, 13, 4182. [CrossRef]

60. Rhodes, A. Digitalisation of Energy; Imperial College London: London, UK, 2020.

61. Osmundsen, K. Competencies for Digital Transformation: Insights from the Norwegian Energy Sector. In Proceedings of the 53rd Hawaii International Conference on System Sciences, Maui, HI, USA, 7-10 January 2020; Volume 3, pp. 4326-4335. [CrossRef]

62. Duch-Brown, N.; Rossetti, F. Digital platforms across the European regional energy markets. Energy Policy 2020, $44,1-11$. [CrossRef]

63. Akberdina, V.; Osmonova, A. Digital transformation of energy sector companies. In Proceedings of the E3S Web of Conferences, 1st Conference on Traditional and Renewable Energy Sources: Perspectives and Paradigms for the 21st Century (TRESP 2021), Prague, Czech Republic, 22-23 January 2021; Volume 250, p. 06001. [CrossRef]

64. Akyazi, T.; Goti, A.; Oyarbide-Zubillaga, A.; Alberdi, E.; Carballedo, R.; Ibeas, R.; Garcia-Bringas, P. Skills requirements for the European machine tool sector emerging from its digitalization. Metals 2020, 10, 1665. [CrossRef]

65. Backa, L.; Wihersaari, M. Future engineering education: What competencies are energy companies looking for when recruiting graduates with a master of science (technology) degree? Eng. Educ. 2014, 9, 2-17. [CrossRef]

66. Brent, D.A.; Ward, M.B. Energy efficiency and financial literacy. J. Environ. Econ. Manag. 2018, 90, 181-216. [CrossRef]

67. Kwiotkowska, A.; Gajdzik, B.; Wolniak, R.; Vveinhardt, J.; Gębczyńska, M. Leadership competencies in making Industry 4.0 effective: The case of Polish heat and power industry. Energies 2021, 14, 4338. [CrossRef]

68. Ahmad, T.; Zhang, D. A critical review of comparative global historical energy consumption and future demand: The story told so far. Energy Rep. 2020, 6, 1973-1991. [CrossRef]

69. Janiszewska, D.A. Diversification of energy production and consumption in European Union countries. Energy Policy J. 2019, 22, 5-20. [CrossRef]

70. Spaiser, V.; Ranganathan, S.; Swain, R.B.; Sumpter, D.J.T. The sustainable development oxymoron: Quantifying and modelling the incompatibility of sustainable development goals. Int. J. Sustain. Dev. World Ecol. 2016, 24, 457-470. [CrossRef]

71. Wu, G.; Liu, D.; Yan, Y. Sustainable development and ecological protection associated with coal-fired power plants in China. Int. J. Sustain. Dev. World Ecol. 2016, 24, 385-388. [CrossRef]

72. Lovati, M.; Huang, P.; Olsmats, C.; Yan, D.; Zhang, X. Agent based modelling of a local energy market: A study of the economic interactions between autonomous PV owners within a micro-grid. Buildings 2021, 11, 160. [CrossRef]

73. Al Mamun, M.; Sohag, K.; Shahbaz, M.; Hammoudeh, S. Financial markets, innovations and cleaner energy production in OECD countries. Energy Econ. 2018, 72, 236-254. [CrossRef]

74. Marks-Bielska, R.; Bielski, S.; Pik, K.; Kurowska, K. The importance of renewable energy sources in Poland's energy mix. Energies 2020, 13, 4624. [CrossRef]

75. Yang, F.; Cheng, Y.; Yao, X. Influencing factors of energy technical innovation in China: Evidence from fossil energy and renewable energy. J. Clean. Prod. 2019, 232, 57-66. [CrossRef]

76. Sunthonkanokpong, W. Future global visions of engineering education. Procedia Eng. 2011, 8, 160-164. [CrossRef]

77. Hill, D.; Ireland, Y.; Yaremko, J.; Harvey, C.; Sahney, R. Investigation and Adoption of APGA's Pipeline Engineer Competency System: The Canadian Experience. In Proceedings of the 2020 13th International Pipeline Conference, 2, Virtual, Online, 28-30 September 2020. [CrossRef]

78. Busu, M. Applications of TQM Processes to Increase the Management Performance of Enterprises in the Romanian Renewable Energy Sector. Processes 2019, 7, 685. [CrossRef]

79. Vaz, M.A.; Brandao, S.N.; Silva, W.N.; Souza, J.M. A Competence Management Model of a Energy Company. In Proceedings of the IADIS International Conference e-Society, Porto, Portugal, 18-21 March 2010; pp. 249-256.

80. Gurieiev, V.; Kutsan, Y.; Iatsyshyn, A.; Iatsyshyn, A.; Kovach, V.; Lysenko, E.; Artemchuk, V.; Popov, O. Simulating systems for advanced training and professional development of energy specialists in power sector. In Proceedings of the 16th International Conference on ICT in Education, Research and Industrial Applications. Integration, Harmonization and Knowledge Transfer. Volume II: Workshops, Kharkiv, Ukraine, 6-10 October 2020; Volume 2732, pp. 693-708.

81. Dimitrov, M.; Venelinova, N. Smart, Secure and Safe Energy Management Approach-An Education Framework Improving the Competence Grid of the Professionals in the Energy Sector. In Proceedings of the 20th International Conference Knowledge-Based Organization, Sibiu, Romania, 13-15 June 2019; Volume XXV/1, pp. 213-218. [CrossRef]

82. Lacerenza, C.N.; Marlow, S.L.; Tannenbaum, S.I.; Salas, E. Team development interventions: Evidence-based approaches for improving teamwork. Am. Psychol. 2018, 73, 517-531. [CrossRef] [PubMed]

83. Isaac, O. Contribution of Employee Competency and Teamwork on Organisational Performance Within Private Sector Organisations in Saudi Arabia. Res. J. Appl. Sci. 2017, 12, 55-66. [CrossRef] 
84. Britt Skjerve, A.; Holmgren, L. Teamwork competence required across operational states: Findings from nuclear power plant operation. In Safety and Reliability_Safe Societies in a Changing World; Haugen, S., Barros, A., van Gulijk, C., Kongsvik, T., Vinnem, J.E., Eds.; Taylor \& Francis Group: London, UK, 2018; pp. 299-307. ISBN 978-0-8153-8682-7.

85. Stagl, K.C.; Burke, C.S.; Salas, E.; Pierce, L. Team adaptation: Realizing team synergy. In Understanding Adaptability: A Prerequisite for Effective Performance within Complex Environments; Burke, C.S., Pierce, L.G., Salas, E., Eds.; Elsevier: Amsterdam, The Netherlands, 2006; pp. 117-141. ISBN 9781351174664.

86. Hillerbrand, R.; Milchram, C.; Schippl, J. Using the capability approach as a normative perspective on energy justice: Insights from two case studies on digitalisation in the energy sector. J. Hum. Dev. Capabil. 2021, 22, 336-359. [CrossRef]

87. Kangas, H.L.; Ollikk, K.; Ahola, J.; Kim, Y. Digitalisation in wind and solar power technologies. Renew. Sust. Energ. Rev. 2021, 150, 111356. [CrossRef]

88. Yu, S.; Ko, Y. Communication competency as a mediator in the self-leadership to job performance relationship. Collegian 2017, 24, 421-425. [CrossRef]

89. Gitelman, L.; Kozhevnikov, M. New Leaders for Technological Breakthroughs In The Energy. WIT Trans. Ecol. Environ. 2017, 224, 499-511. [CrossRef]

90. Ali, M. Vocational students' perception and readiness in facing globalization, industry revolution 4.0 and society 5.0. J. Phys. Conf. Ser. 2021, 1833, 012050. [CrossRef]

91. Latif, N.A.; Nor, M.Y. Continuous quality improvement (cqiCQI) practice in vocational colleges. Int. J. Mod. Educ. 2021, 3, 211-225. [CrossRef]

92. Ahmed, W.; Moazzam, M.; Sarkar, B.; Ur Rehman, S. Synergic Effect of Reworking for Imperfect Quality Items with the Integration of Multi-Period Delay-in-Payment and Partial Backordering in Global Supply Chains. Engineering 2021, 7, 260-271. [CrossRef]

93. Musembi, A.K.K.; Guyo, W.; Kyalo, D.N.; Mbuthia, A. Effect of employees' soft skills on performance of public energy sector projects in Kenya. Int. Acad. J. Hum. Press. Bus. Adm. 2018, 3, 1-13.

94. Sahin, U. Future of renewable energy consumption in France, Germany, Italy, Spain, Turkey and UK by 2030 using optimized fractional nonlinear grey Bernoulli model. Sustain. Prod. Consum. 2021, 25, 1-14. [CrossRef] [PubMed]

95. Kudelin, A.; Kutcherov, V. Wind Energy in Russia: The current state and development trends. Energy Strategy Rev. 2021, 34, 100627. [CrossRef]

96. Anser, M.K.; Shabbir, M.S.; Tabash, M.I.; Shah, S.H.A.; Ahmad, M.; Peng, M.Y.P.; Lopez, L.B. Do renewable energy sources improve clean environmental-economic growth? Empirical investigation from South Asian economies. Energy Explor. Exploit. 2021, 39, 1491-1514. [CrossRef]

97. Belançon, M.P. Brazil electricity needs in 2030: Trends and challenges. Renew. Energy Sources 2021, 36, 89-95.

98. McGreevy, M.; MacDougall, C.; Fisher, M.; Henley, M.; Baum, F. Expediting a renewable energy transition in a privatised market via public policy: The case of South Australia 2004-18. Energy Policy 2021, 148, 111940. [CrossRef]

99. Jędra, M. Transformacja Energetyczna w Polsce; Edycja 2021; Forum Energia: Warszawa, Poland, 2021. 